\title{
CLAY AND PHOSPHORUS LOSSES BY EROSION IN OXISOL WITH SUGARCANE RESIDUES
}

Doi:http://dx.doi.org/10.1590/1809-4430-Eng.Agric.v36n6p1063-1072/2016

\section{DANIELA T. DE PAULA ${ }^{1 *}$, MARCÍLIO V. MARTINS FILHO ${ }^{2}$, VERA L. DA S. FARIAS ${ }^{2}$, DIEGO S. SIQUEIRA ${ }^{2}$}

${ }^{1 *}$ Corresponding author. Universidade Estadual Paulista/ Jaboticabal - SP, Brasil. E-mail: dani_mestra@ hotmail.com

ABSTRACT: Considering the importance of nutrients in the soil for the plants development and the soil quality conservation and the quantification relevance of them for proper soil management, the aims of this research were: (i) to quantify the clay loss, adsorbed and soluble P from interrill erosion influenced by the presence of sugarcane residues on the ground surface; (ii) to determine the minimum percentage of residues to be maintained on the soil surface to not enrich the eroded sediment by clay and soluble $\mathrm{P}\left(\mathrm{P}_{\mathrm{sed}}\right)$ and adsorbed $\left(\mathrm{P}_{\mathrm{ads}}\right)$. The experimental area is located in Guariba - SP, with soil classified as Red Dystrophic Oxisol. The experiment was designed based on results of previous experiments with residue analysis of variance for 40 plots. These experiments were conducted by our research group, which provided field representation and the establishment of a minimum number of degrees of freedom necessary to ensure normal distribution of results and variance homoscedasticity. The experimental design was completely randomized in a factorial design, 5 treatments with straw sugarcane and 3 repetitions, totaling 15 plots. In the treatments, the straw was manually distributed across the surface of the soil in amounts of $0 ; 0.16 ; 0.35 ; 0.52$ to 0.7 $\mathrm{Kg}$ by plot, giving 0\% coverage $\left(\mathrm{SC}_{0}\right), 25 \%\left(\mathrm{SC}_{25}\right), 50 \%\left(\mathrm{SC}_{50}\right), 75 \%\left(\mathrm{SC}_{75}\right)$ and $100 \%\left(\mathrm{SC}_{100}\right)$, respectively. The experimental plots were subjected to simulated rain with average intensity of 60 $\mathrm{mm} \mathrm{h}^{-1}$ for 65 minutes. To avoid enrichment ratio (ER) of the sediment eroded by $\mathrm{P}_{\text {sed }}, \mathrm{P}_{\text {ads }}$ and clay, a minimum soil surface coverage ( $\mathrm{SC}$ ) of $42 \%$ is necessary.

KEYWORDS: interrill erosion, simulated rainfall, vegetation cover.

\section{INTRODUCTION}

Erosion is a natural physical process that consists of the breakdown, transportation and deposition of soil particles, which begins with the impact of raindrops on the soil surface, when associated with agricultural activities can be intensified due to the use of inappropriate agricultural practices and the reduction of vegetation cover (SILVA \& CONCEIÇÃO, 2011). Estimates indicate loss of 30 million $\mathrm{T}$ year ${ }^{-1}$ of $\mathrm{N}$ and 17.5 million $\mathrm{T}$ year ${ }^{-1}$ of $\mathrm{P}$, compromising soil fertility (QUINTON et al., 2010).

In the absence of vegetation, the soil is unprotected, when there is incidence of rain on it, the particles can break down, sealing it and hampering the water infiltration, facilitating runoff, which promotes the drag and suspension of the broken soil particles, where organic matter and nutrients used in agricultural production are present (SILVA et al., 2012).

The runoff promotes the transport of nutrients and small particles such as: organic carbon, phosphorus, nitrogen and clay, enriching the eroded sediment (HU et al., 2013).

The transported particles from the soil superficial erosion promote pollution and siltation of rivers (PINHEIRO et al., 2013). Moreover, they decrease soil fertility and cause the accumulation of waste and chemical pesticides, damaging aquatic flora and fauna (RAMOS et al., 2012) resulting in a lower $\mathrm{O}_{2}$ concentration in the water, characterizing a phenomenon called eutrophication (FAZLI et al., 2011; PINHEIRO et al., 2013). With this phenomenon there is the proliferation of aquatic weeds and algae that can produce harmful toxic substances to health, changing the water quality (BARRETO et al., 2013).

\footnotetext{
${ }^{2}$ Universidade Estadual Paulista/ Jaboticabal - SP, Brasil. 
The impacts caused by erosion can be minimized by using alternative soil cultivation systems (ATUCHA et al., 2013), among them the use of conservation systems that keep the waste on the surface and no soil preparation (TRUMAN et al., 2009).

The presence of live or dead plant cover on the soil surface intercepts the raindrops impact on the ground, protecting it (CARDOSO et al., 2012).Consequently, there is the reduction of the surface sealing formation and soil disaggregation, preserving the physical properties of the soil, reducing erosion (PANACHUKI et al., 2011).

SOUSA et al. (2012) evaluated the soil losses, nutrients and organic matter in the eroded sediment, in the absence and presence of vegetation cover by sugarcane residues and observed that soil losses and organic matter, as the concentration of nutrients in the sediment, were lower in plots with $50 \%$ or more coverage with sugarcane straw.

Given the above and considering the importance of nutrients in the soil for plant development and the conservation of soil and water quality, as well as the importance of quantifying the same for proper soil management, this research aimed to: (i) to quantify the loss of clay, soluble P adsorbed by interrill erosion, influenced by the presence of sugarcane residue on the soil surface; (ii) determine the minimum percentage of residue to be retained on the soil surface to prevent loss of clay and phosphorus.

\section{MATERIAL AND METHODS}

The area is located in the northeast of the State of São Paulo, in the municipality of Guariba. The geographic coordinates are $21^{\circ} 19^{\prime}$ South latitude and $48^{\circ} 13^{\prime}$ west longitude, with an average altitude of $640 \mathrm{~m}$ above sea level.

The climate, according to Köppen classification, is the mesothermal type with dry winter (Aw) and an average rainfall of 1,400 $\mathrm{mm}$, with rainfall concentrated in the period from November to February. The natural vegetation consists of semi-deciduous tropical forest.

The soil of the experimental area was classified as Red Dystrophic Oxisol (EMBRAPA SOLOS, 2013); which values of the main physical and chemical properties are shown in Table 1.

TABLE 1 . Soil physical and chemical attributes in the depth of 0 to $0.2 \mathrm{~m}$.

\begin{tabular}{|c|c|c|c|c|c|c|c|c|c|c|c|c|c|c|}
\hline Clay & Silt & Sand & pH & OM & $\mathbf{P}($ resin) & $\mathbf{P}$ (ads) & $\mathbf{K}$ & $\mathbf{C a}$ & Mg & Al & $\mathbf{H}+\mathbf{A l}$ & TS & CEC & V \\
\hline 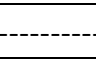 & $\mathrm{kg}^{-1}$ & 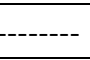 & $\mathrm{CaCl}_{2}$ & $\mathrm{~g} \mathrm{~kg}^{-1}$ & $\mathrm{mg} \mathrm{dm}^{-3}$ & $\mathrm{mg} \mathrm{dm}^{-3}$ & \multicolumn{7}{|c|}{ - $\mathrm{mmol}_{\mathrm{c}} \mathrm{dm}^{-3}$} & $\%$ \\
\hline 630 & 70 & 300 & 5 & 23 & 47 & 385 & 2 & 32 & 9 & 1 & 35 & 43 & 79 & 63 \\
\hline
\end{tabular}

A plot with more than 20 consecutive years with sugarcane cultivation was selected. The vegetation coverage in the area, at the time of this research, consisted of sugarcane residues, which were kept on the surface after the mechanical harvesting of the crop.

The experimental plots with an average slope of $5 \%$ had the following dimensions: $0.5 \mathrm{~m}$ of width by $1 \mathrm{~m}$ in length (total area of $0.5 \mathrm{~m}^{2}$ ) and delimited by metal plates on their sides, and top and bottom by a convergent rail to an exit of $0.1 \mathrm{~m}$ of diameter to determine the erosion process in the interrill.

The experiment was designed based on results of previous experiments with residue variance analysis for 40 plots. These experiments were conducted by our research group, which provided field representation and the establishment of a minimum number of degrees of freedom necessary to ensure normal results distribution and variance homoscedasticity. Thus, the experimental design was completely randomized: five treatments with sugarcane straw and three repetitions, totaling 15 plots. 
In the treatments, the straw was manually distributed across the soil surface, in quantities of 0 ; $0.16 ; 0.35 ; 0.52$ and $0.70 \mathrm{~kg}$ per plot according to SILVA et al. (2012), providing coverage of 0\% $\left(\mathrm{SC}_{0}\right), 25 \%\left(\mathrm{SC}_{25}\right), 50 \%\left(\mathrm{SC}_{50}\right), 75 \%\left(\mathrm{SC}_{75}\right)$ and $100 \%$ ( $\left.\mathrm{SC}_{100}\right)$, respectively.

Control plots were the ones without straw coverage $\left(\mathrm{SC}_{0}\right)$. To establish the straw mass aiming to obtain the value of $100 \%$ coverage, several samples were weighed in areas of $1 \mathrm{~m}^{2}$ of straw after the harvest and the samples average mass was determined. The straw application was carried out two hours before the simulated rain, with an average intensity of $60 \mathrm{~mm} \mathrm{~h}^{-1}$ for 65 minutes. It was used a rain simulator of rotating rods of Swanson type, equipped with VeeJet 80-100 nozzles. The equipment was calibrated and leveled in the ground, as described by MARTINS FILHO et al. (2009).

Thirty-three pluviometers, lined up on the slope, in the action area of the rainfall simulator were used to determine the rainfall intensity produced by the simulator, in the areas occupied with the experimental plots.

Sampling for measurements of runoff flow rates and sediment concentrations were carried out in the fifth minute after the flood start and, thereafter, every five minutes. Samples were collected in plastic containers with $1 \mathrm{~L}$ capacity, timing the collection time. Shortly after the collection, the containers were sealed and taken to the laboratory to quantify the sediment concentration and solution volume, and consequently the determination of soil and water losses rates.

The collected solution volumes were evaluated, in balance with resolution of $0.01 \mathrm{~g}$ and then the samples were left to rest for 24 hours to sediment deposition. After the 24-hour period of rest, the supernatant was filtered and subjected to analysis for the determination of $\mathrm{P}, \mathrm{K}, \mathrm{Ca}$ and $\mathrm{Mg}$, following the EMBRAPA SOLOS method (2011). The decanted material was taken to the greenhouse at $60^{\circ} \mathrm{C}$ until completely drying. After drying, the samples were weighed, determining the sediment weight of each one. The sediment concentration was obtained considering the solution volume, the water and the sediment density in the solution. Each one of the solution volume obtained was divided by the collection time, obtaining the flood flow in each collection interval.

Once quantified the eroded sediment in $\mathrm{kg} \mathrm{s}^{-1}$ and the flow rate in $\mathrm{m}^{3} \mathrm{~s}^{-1}$, for each sample, the erosion and runoff rates were determined by dividing each one of the values obtained by the plot area. Deformed samples were collected in the borders of the interrill plots, with the aid of an auger, in the layer range from 0 to $0.15 \mathrm{~m}$, for soil moisture determination, which was determined gravimetrically by drying in an oven under forced circulation, at $105{ }^{\circ} \mathrm{C}$ for 24 hours. The gravimetric moisture was expressed in $\mathrm{g} \mathrm{g}^{-1}$ and subsequently converted into $\mathrm{m}^{3} \mathrm{~m}^{-3}$, using the soil bulk density.

The superficial runoff rate was obtained by measuring the time taken for a dye $(0.25 \%$ methylene blue) to cover a distance of $0.50 \mathrm{~m}$ in the experimental plot. Such measurements were taken every five minutes during the simulated rain. A certain speed is considered the maximum flow velocity. The average flow velocity was established according to SILVA et al. (2012), which is given by the product of the maximum speed by an adjustment factor, $\alpha=2 / 3$.

For the chemical characterization of the soil and eroded sediment, $\mathrm{Ca}, \mathrm{Mg}, \mathrm{K}$ and $\mathrm{P}$ were extracted by the ions exchange resin method. The organic carbon $(\mathrm{C} \%)$ wet process was determined using the EMBRAPA SOLOS methodology (2011).The $\mathrm{pH}$ was potentiometrically measured in $\mathrm{CaCl}_{2} 0.01 \mathrm{M}$ solution. The phosphorus adsorption values $(\mathrm{P})$ were obtained by adding a solution with a concentration of $100 \mathrm{mg} \mathrm{L}^{-1}$ of $\mathrm{P}$ in soil samples, being the $\mathrm{P}_{\mathrm{ads}}$ amount calculated by subtracting the value determined in solution of the total amount added.

The disaggregation rate of soil in interrill (Di) was determined according to the [eq. (1)]:

$$
\mathrm{D}_{\mathrm{i}}=\frac{\mathrm{m} \mathbf{s}}{\mathbf{t} \mathbf{A}}
$$


that,

$\mathrm{ms}=$ disaggregated soil mass $(\mathrm{kg})$;

$\mathrm{t}$ is the collection time (s), and

A is the plot area $\left(\mathrm{m}^{2}\right)$.

The total soil losses were determined by [eq. (2)]:

$$
S L=\frac{\sum_{i=1}^{n}\left(Q_{i} C_{i} t\right)}{A}
$$

that,

SL is the total soil loss in interrill $\left(\mathrm{kg} \mathrm{m}^{-2}\right)$;

$\mathrm{Ci}$ is the sediment concentration $\left(\mathrm{kg} \mathrm{L}^{-1}\right)$;

Qi is the flow rate $\left(\mathrm{L} \mathrm{s}^{-1}\right)$;

$\mathrm{t}$ is the interval between collections (300s);

A is the plot area $\left(\mathrm{m}^{2}\right)$, and

$\mathrm{n}$ is the total number of collected samples.

Parameters concerning the hydraulic runoff as the Froude number and Manning roughness coefficient were determined as described in the following.

To obtain the Froude number (Fr), the following expression was used:

$$
\mathrm{Fr}=\frac{\mathrm{v}}{\sqrt{\mathrm{gh}}}
$$

that,

$\mathrm{g}$ is the gravitational acceleration $\left(\mathrm{m} \mathrm{s}^{-2}\right)$;

$\mathrm{h}$ is the height of the water level (m), and

$\mathrm{v}$ is the flow velocity $\left(\mathrm{m} \mathrm{s}^{-1}\right)$.

The hydraulic roughness to the superficial runoff was obtained by determining the Manning roughness coefficient:

$$
\mathrm{n}=\frac{1}{\mathrm{v}} \mathrm{Rh}^{2 / 3} \mathrm{~S}^{1 / 2}
$$

that,

$\mathrm{h}$ is the hydraulic radius (m), and

$\mathrm{S}$ is the slope ratio $\left(\mathrm{m} \mathrm{m}^{-1}\right)$.

The results were submitted to analysis of variance according to a completely randomized design, and for multiple comparisons of the averages, Duncan test at 5\% was used.

\section{RESULTS AND DISCUSSION}

\section{Interrill Erosion}

The influence of coverage by sugarcane waste in surface in the erosion rate and sediment concentration in interrill was verified. 
The increase of the soil surface coverage caused a significant exponential decrease in interrill erosion rate and in the sediment concentration (Figure 1). With $100 \%$ of coverage, there was $0.25 \mathrm{~g}$ of soil sediment being transported per liter of flood, while in the bare soil were dragged $9.03 \mathrm{~g} \mathrm{~L}^{-1}$. With $100 \%$ of coverage a decrease of $99.2 \%$ in the erosion rate in relation to the absence of coverage was observed (Figure 1).

(a)

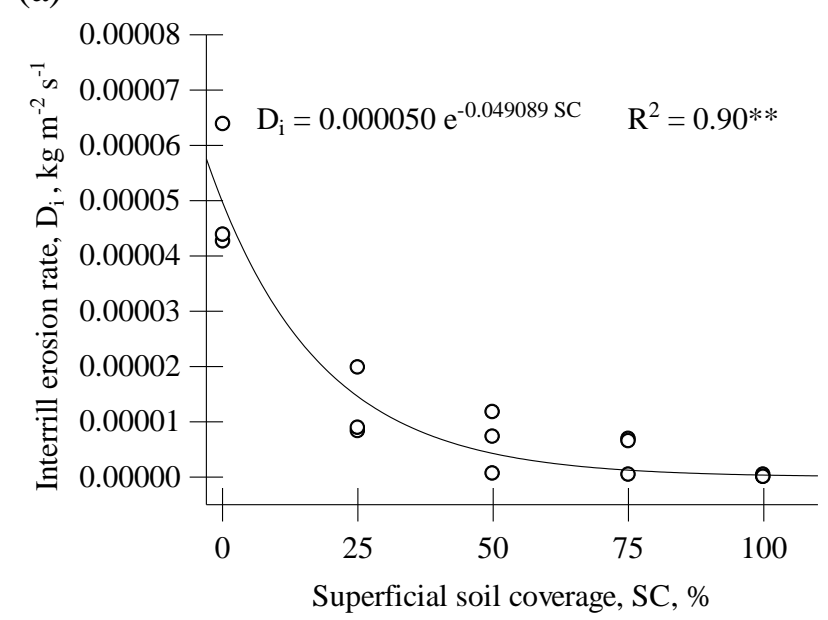

(b)

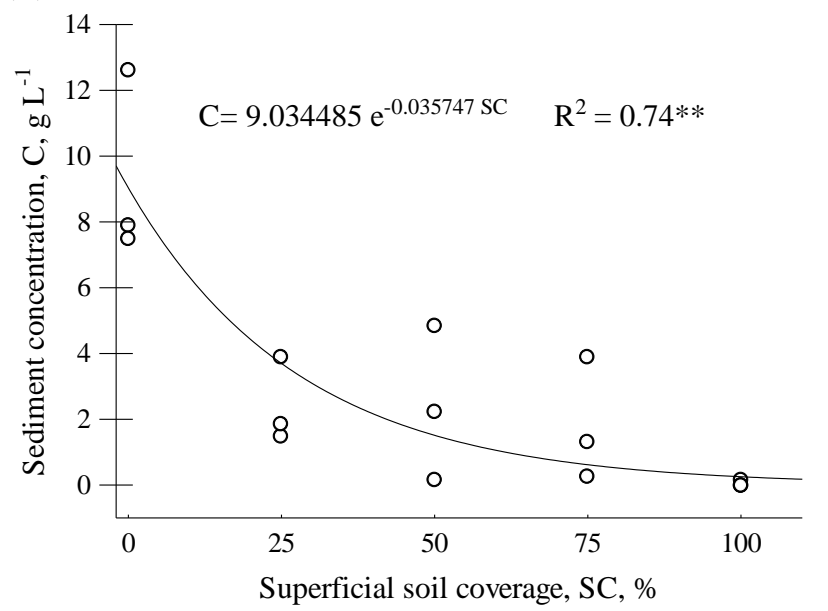

FIGURE 1. Interril erosion rate (a) and concentration of soil sediments in runoff water (b) in function of the soil coverage by sugarcane residues.

When $50 \%$ of straws were kept on the soil surface, the $D_{i}$ was reduced by $91.4 \%$ when compared to the value obtained for bare soil. These results are superior to those observed by SILVA et al. (2012) to interrill erosion in Oxisol similar to this research that reported $85 \%$ of $\mathrm{D}_{\mathrm{i}}$ reduction in this condition. These differences are probably due to the erodibility of the soil and straw amount applied per plot. The sediment concentrations decreased with the increase of soil surface coverage with sugarcane, such behavior also corroborates with the results obtained by SOUSA et al. (2012).

A positive linear relation was obtained between the Manning roughness coefficient (n) and soil surface coverage (SC), such that $\mathrm{n}=0.0398+0.0008 \mathrm{SC}\left(\mathrm{R}^{2}=0.93 * *\right)$. With the increase of soil coverage, there was a proportional increase in flow resistance evaluated by Manning roughness coefficient (n) reducing the sediment concentration in the runoff (Figure 2), which increased the viscous forces and increased the ones related to gravity, decreasing the Froude number (Figure 3), as observed by CANTALICE et al. (2009).

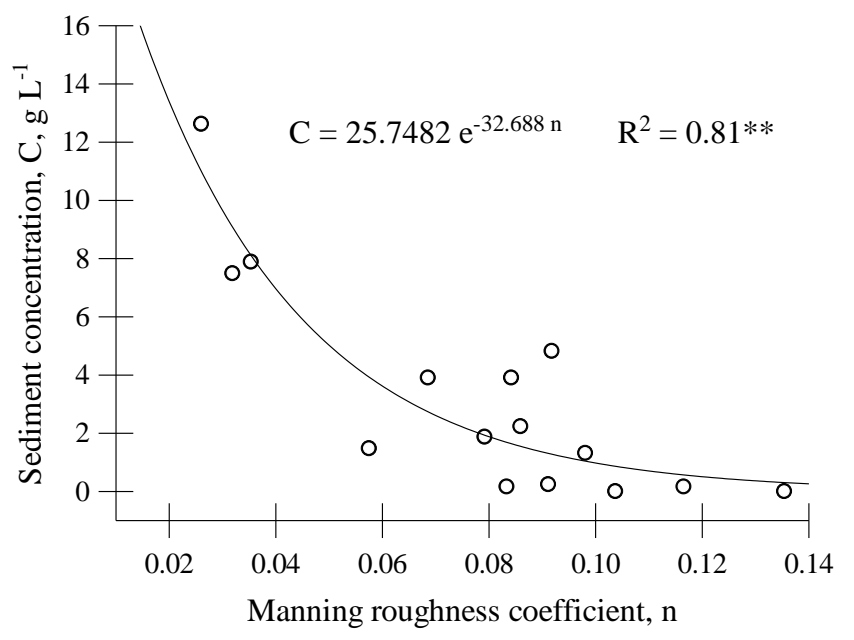

FIGURE 2. Relation between sediments concentration (C) and the Manning roughness coefficient (n). 


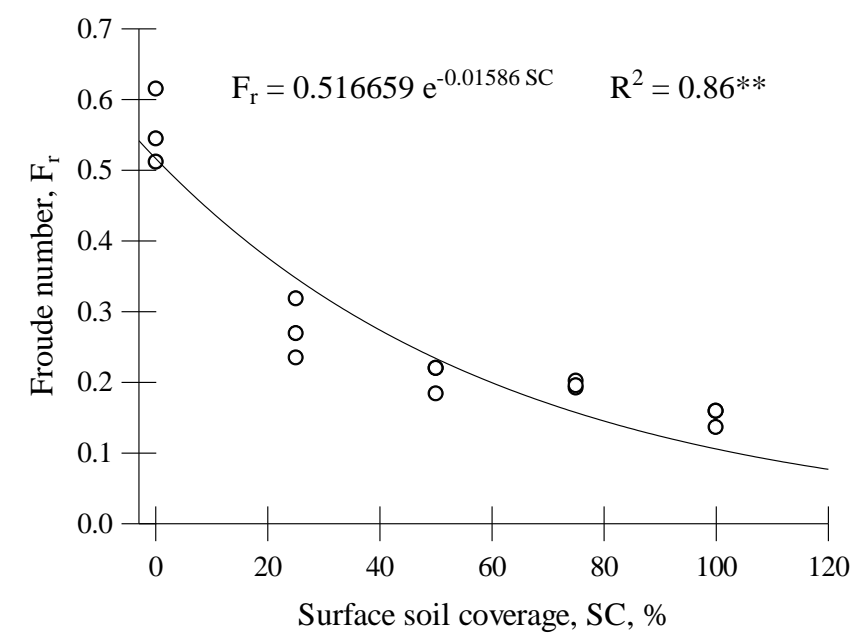

FIGURE 3. Froude number in function of soil surface coverage by sugarcane residues.

These results corroborate with those obtained by MARTINS FILHO et al. (2009), who developed studies using different conditions of coverage in Argisol cultivated with sugarcane, keeping the straw on the soil surface, and concluded that by using the soil surface coverage, soil losses by erosion were reduced in $87 \%$ in relation to the one obtained in the bare soil. In the oxisol of this research, the soil losses were reduced in $99 \%$ with SC of $100 \%$ in relation to SC of $0 \%$.

The effectiveness of soil coverage to reduce erosion was also observed by SOUSA et al. (2012) that when evaluated soil losses of organic matter and nutrients in area with sugarcane cultivation, subjected to mechanical harvesting, using plots with different coverage percentages, concluded that in the plots with $75 \%$ and $100 \%$ of coverage, the erosion losses were significantly reduced.

The vegetation coverage influence on erosion rate was also studied by ATUCHA et al. (2013) who observed that the vegetation with ryegrass in avocado orchards minimized the erosion in $99.96 \%$, as well as other environmental impacts, reducing nutrient losses by runoff in $79.7 \%$ for $\mathrm{N}$ and in $94.1 \%$ for $\mathrm{P}$, comparing to the bare soil. In this research, the reductions in losses of $\mathrm{P}$ were in order of $66.7 \%$ with SC of $100 \%$ in relation to the bare soil.

\section{Losses of Clay, Available and Adsorbed Phosphorus in the Sediment}

Figure 4 shows the clay content of the eroded sediment correlated with the increased soil losses by interrill erosion. This fact is directly linked to a greater or lesser coverage provided to the soil, which can be understood from the results expressed in Figure 5.

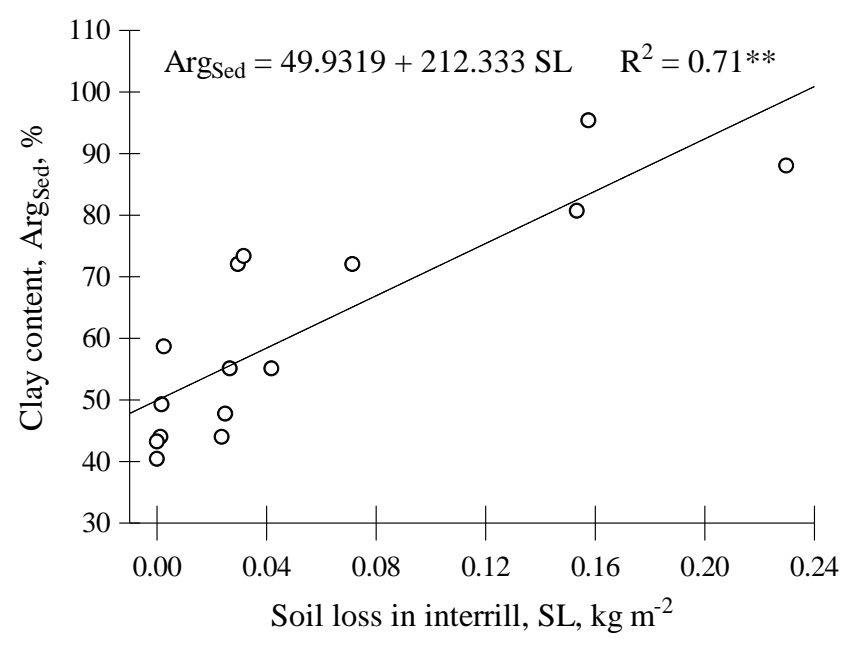

FIGURE 4. Relation between clay content in the sediment and the soil loss in interril. 


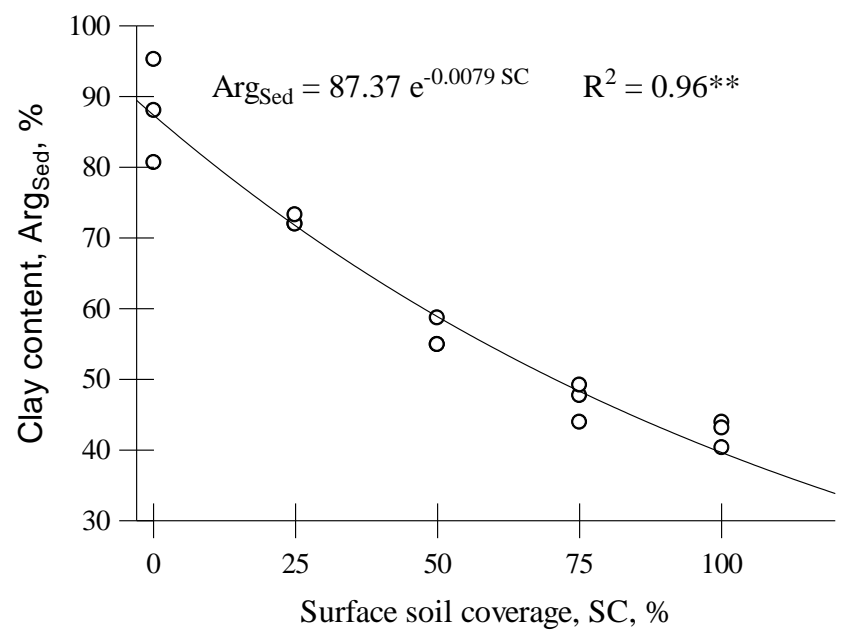

FIGURE 5. Clay content in eroded sediment depending on soil surface coverage.

In Figure 6 there is the amount of available phosphorus and adsorbed phosphorus to the eroded sediment, which increases linearly with the increase of clay content present in the sediment. This happens because the phosphorus is absorbed by minerals in the clay fraction as hematite, goethite, gibbsite and kaolinite. In the region of the research, $1.0 \mathrm{~kg}$ of soil contains approximately $20 \mathrm{~g}$ of goethite and 30 to $60 \mathrm{~g}$ of hematite. In this $1 \mathrm{~kg}$ of soil can be absorbed 401 to $552 \mathrm{mg}$ of phosphorus (CAMARGO et al., 2015).

(a)

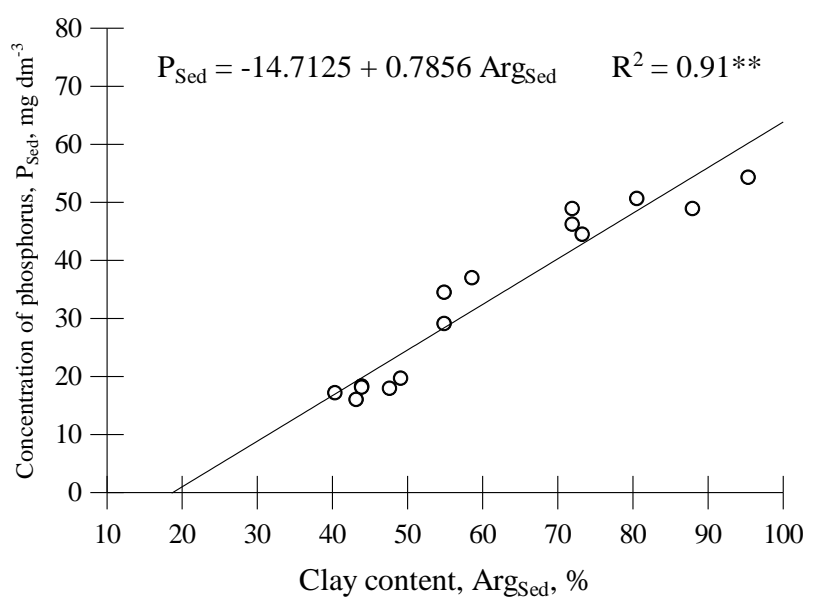

(b)

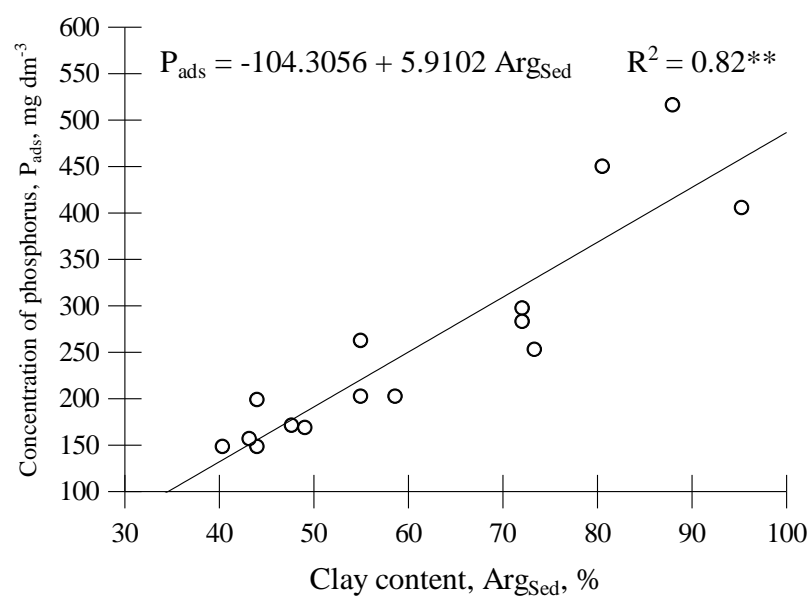

FIGURE 6. Amount of phosphorus depending on the clay content in the eroded sediment: a) concentration of soluble phosphorus $\left(\mathrm{P}_{\text {sed }}\right)$; b) concentration of adsorbed phosphorus ( $\left.\mathrm{P}_{\mathrm{ads}}\right)$.

The enrichments of the eroded sediment by clay and phosphorus are, likely, consequences of a strong selective erosion which preferably carries the particles of smaller diameter and low density, which is common in interrill erosion (MARTINS FILHO et al., 2009) and is related to the enrichment of eroded sediment by thin low density fractions as silt, clay, phosphorus, nitrogen and organic carbon of the soil (HU et al., 2013). Thus, the sediment enrichment by phosphorus can be attributed to the phosphorus association with the finer soil fractions, which are preferably dragged (KUHN et al., 2010).

The enrichment ratios (ER) in Figures $7 \mathrm{a}$ and $7 \mathrm{~b}$ are the relation between the concentration of soluble $\mathrm{P}$ and adsorbed $\mathrm{P}$ in the eroded sediment and the original soil (Table 1).When ER is greater than 1 that means the segment is enriched with organic matter and soil nutrients (MARTINS FILHO et al., 2009). For SILVA et al (2012), the enrichment rates greater than 1 indicate selectivity of the material dragging in the interrill erosion, which mainly carries the finer particles, the most 
reactive fractions of the soil and, consequently, with higher capacity of carrying organic carbon and nutrients.

Considering the eroded sediment ER by $\mathrm{P}_{\text {Sed }}$ and $\mathrm{P}_{\mathrm{ads}}$ (Figure $7 \mathrm{a}$ and $7 \mathrm{~b}$ ), a minimum SC of $18 \%$ and $10 \%$ would be necessary to the ER to be equal to 1 , so there is no eroded sediment enrichment with available and adsorbed phosphorus, respectively. Such coverage, however, does not guarantee the absence of sediment enriched with clay and/or other nutrients at levels capable of conducting an ER $\leq 1$. Furthermore, they are lower than the ones determined by SILVA et al. (2012) in Oxisol similar to this research, which evaluate for ER $\leq 1$, in case of $\mathrm{P}$ has the need of a $\mathrm{SC} \geq 25 \%$. These differences are probably due to higher ER rates obtained by SILVA et al. (2012), 2.1 for SC of $0 \%$ and $0.5 \%$ for SC of $100 \%$, regarding the ones of this research of 1.3 for SC of $0 \%$ and 0.4 for SC of $100 \%$.

(a)

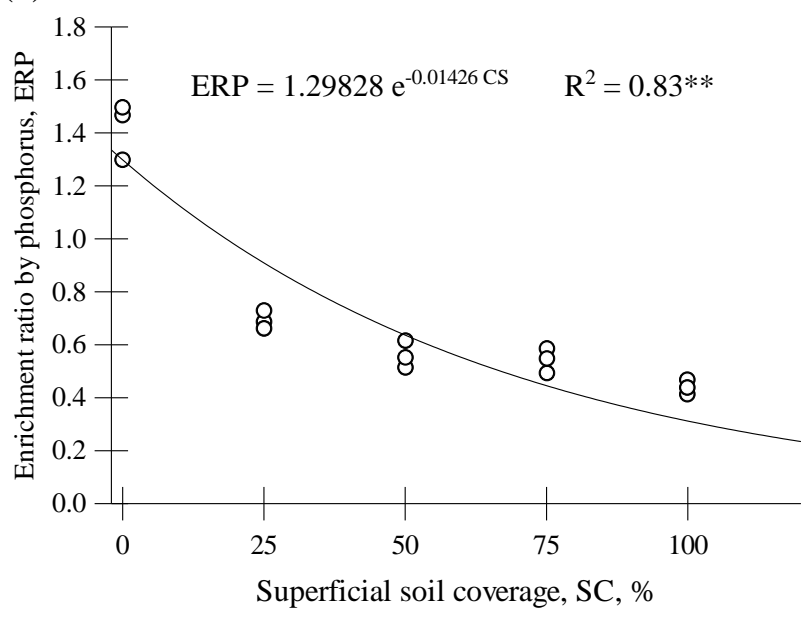

(b)

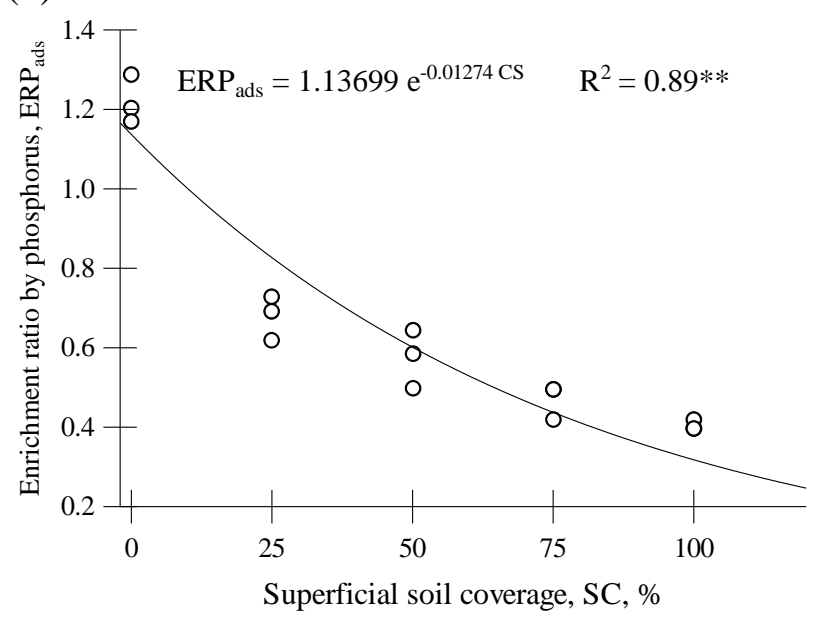

FIGURE 7. Eroded sediment enrichment ratio (ER) depending on soil surface coverage for sugarcane residues. a) available phosphorus (ERP) and b) adsorbed phosphorus (ERP $\left.{ }_{\text {ads }}\right)$.

In the specific case of sediment enrichment rate by clay $\left(\mathrm{ER}_{\mathrm{Cla}}\right)$, depending on the soil surface coverage by sugarcane residues (SC), the following linear relation was obtained: $E_{\mathrm{Cla}}=1.39021 \mathrm{e}^{-}$ $0.00788 \mathrm{SC}\left(\mathrm{R}^{2}=0.95^{* *}\right)$. Thus, for an $\mathrm{ER}_{\mathrm{Cla}} \leq 1$, a $\mathrm{SC} \geq 42 \%$ would be necessary. Such soil surface coverage also ensures ERP and $\mathrm{ERP}_{\mathrm{ads}}$ less than 1. These results, like those obtained by KLEINMAN et al. (2011), allow to understand the opportunities and limitations of P management strategies, which is essential to ensure that the water quality expectations derived from agricultural areas are realistic and the management practices are efficient and effective.

\section{CONCLUSIONS}

High soil roughness values, by the presence of plant residues on the soil surface, imply the exponential reduction of sediment concentration and the Froude number, characterizing slow flow regime, typical of the interrill erosion.

There are positive linear relations between the concentrations of soluble and adsorbed phosphorus with clay content in the eroded sediment.

A minimum soil surface coverage of $42 \%$ is necessary so there is no enrichment rate of the eroded sediment by clay and, consequently by available and adsorbed phosphorus.

\section{REFERENCES}

ATUCHA, A.; MERWIN, I. A.; BROWN, M. G.; GARDIAZABAL, F.; MENA, F.;

ADRIAZOLA, C.; LEHMANN, J. Soil erosion, runoff and nutrient losses in an avocado (Persea Americana Mill) hillside orchard under different groundcover management systems. Plant Soil, Dordrecht, v. 368, n. 1-2, p. 393-406, 2013. 
BARRETO, L. V.; BARROS, F. M.; BONOMO, P.; ROCHA, F. A.; AMORIM, J. S. Eutrofização em rios brasileiros. Enciclopédia Biosfera, Centro Científico Conhecer - Goiânia, v.9, n.16, p.2167, 2013.

CAMARGO, L. A.; MARQUES JUNIOR, J.; BARRÓN, V.; ALLEONI, L. R. F. ; BARBOSA, R. S.; PEREIRA, G. T. Mapping of clay, iron oxide and adsorbed phosphate in Oxisols using diffuse reflectance spectroscopy. Geoderma, Amsterdam, v. 251-252, p.124-132, 2015.

CANTALICE, J. R. B.; BEZERRA, S. A.; OLIVEIRA, O. F. L.; MELO, R. O. Hidráulica e taxas de erosão em entressulcos sob diferentes declividade e doses de cobertura morta. Revista Caatinga, Mossoró, v.22, n.2, p.68-74, 2009.

CARDOSO, D.P.; SILVA, M. L. N.; CARVALHO, G. J.; FREITAS, D. A. F.; AVANZI, J. C. Plantas de cobertura no controle das perdas de solo, água e nutrientes por erosão hídrica. Revista Brasileira de Engenharia Agrícola e Ambiental, Campina Grande, v.16, n.6, p.632-638, 2012. Disponível em: <http://www.agriambi.com.br>. Acesso em: 6 dez 2014.

EMBRAPA SOLOS - EMPRESA BRASILEIRA DE PESQUISA AGROPECUÁRIA. Ministério da Agricultura, Pecuária e Abastecimento. Sistema brasileiro de classificação de solos. 3.ed. Brasília, DF, 2013. 353 p.

EMBRAPA SOLOS - EMPRESA BASILEIRA DE PESQUISA AGROPECUÁRIA. Manual de métodos de análise dos solos. 2. ed. Rio de Janeiro, 2011. 230p.

FAZLI, S.; MIRNIA, S.K., NOOR, H. Effect of soil erosion on available phosphorus losses in a Hyrcanian watershed. Environmental Erosion Researches, Hormozgan, v.1, n.2, p.43-52, 2011.

HU, Y.; FISTER, W.; KUHN, N. Temporal variation of SOC enrichment from interrill erosion over prolonged rainfall simulations. Agriculture, Basel, v. 3, n. 4, p. 726-740, 2013.

doi:10.3390/agriculture3040726.

KLEINMAN, P.J.A.; SHARPLEY, A.N.; McDOWELL, R.W.; FLATEN, D.N.; BUDA, A.R.; TAO, L.; BERGSTROM, L.; ZHU, Q. Managing agricultural phosphorus for water quality protection: principles for progress. Plant and Soil, Dordrecht, v.349, n.1, p.169-182, 2011.

KUHN, N. J.; ARMSTRONG, E. K.; LING, A. C.; CONNOLLY, K. L. Interril erosion of carbon and phosphorus from conventionally and organically farmed devon silts soils. Catena, Amsterdam, v. 57, p. 113-133, 2010.

MARTINS FILHO, M. V.; LICCIOTI, T. T.; PEREIRA, G. T.; MARQUES JÚNIOR, J.;

SANCHEZ, R. B. Perdas de solo e nutrientes por erosão num Argissolo com resíduos vegetais de cana-de-açúcar. Engenharia Agrícola, Jaboticabal, v.29, n.1, p.8-18, 2009.

PANACHUKI, E.; BERTOL, I.; SOBRINHO, T. A.; OLIVEIRA, P. T. S; RODRIGUES, D. B. B. Perdas de solo e de água e infiltração de água em Latossolo Vermelho sob sistema de manejo.

Revista Brasileira de Ciência do Solo, Viçosa, MG, v. 35, n. 5, p. 1777-1785, 2011.

PINHEIRO, A.; KAUFMANN, V.; SHNEIDERS, D.; GOTARDO, R. Transporte de sedimentos e espécies químicas em áreas de reflorestamentos e pastagem com base em chuva simulada. Revista Ambiente \& Água, Taubaté, v. 8, n. 2, p. 109-123, 2013.

QUINTON, J. N.; GOVERS, G.; VAN OOST, K.; BARDGETT, R.D. The impact of agricultural soil erosion on biogeochemical cycling. Nature Geoscience, New York, v. 3, p. 311-314, 2010.

RAMOS, Y.S.; RIBEIRO, G.N.; ROCHA, R.N.R. Erosão laminar e atributos físico-químicos de solos próximos a Usina Hidrelétrica Luiz Gonzaga/PE. Agropecuária Científica no Semiárido, Campina Grande, v.8, n.3, p.74-84, 2012.

SILVA, D.J.; CONCEIÇÃO, G.M. Caracterização Geoambiental e Socioambiental, Município de Caxias, Maranhão, Brasil. Scientia Plena, Aracaju, v.7, n.1, p.1-26, 2011. 
SILVA, G. R. V.; SOUSA, Z. M.; MARTINS FILHO, M. V.; BARBOSA, R. S.; SOUSA, G. S. Soil, water and nutrient losses by interrill erosion from green cane cultivation. Revista Brasileira de Ciência do Solo, Viçosa, MG, v. 36, n. 3, p. 963-970, 2012.

SOUSA, G. B.; MARTINS FILHO, M. V.; MATIAS, S. S. R. Perdas de solo, matéria orgânica e nutrientes por erosão hídrica em uma vertente coberta com diferentes quantidades de palha de canade-açúcar em Guariba-SP. Engenharia Agrícola, Jaboticabal, v.32, n.3, p.490-500, 2012.

TRUMAN, C. C.; SHAW, J. N.; FLANAGAN, D. C.; REEVES, D. W. Conservation tillage to effectively reduce interrill erodibility of highly weathered ultisols. Journal of Soil and Water Conservation, Ankeny, v. 64, n. 4, p. 265-275, 2009. 